\title{
Effect of antioxidants coenzyme Q10 and $\beta$-carotene on the cytotoxicity of vemurafenib against human malignant melanoma
}

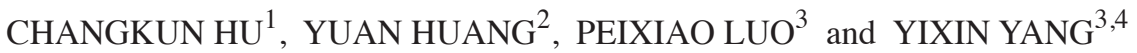 \\ ${ }^{1}$ Division of Biology, Kansas State University, Manhattan, KS 66506, USA; ${ }^{2}$ Department of Hematopathology, \\ Anqing Municipal Hospital, Anqing, Anhui 246004; ${ }^{3}$ School of Natural Sciences, College of Science and Technology, \\ Wenzhou Kean University, Wenzhou, Zhejiang 325035, P.R. China; ${ }^{4}$ School of Natural Sciences, The Dorothy and \\ George Hennings College of Science, Mathematics and Technology, Kean University, Union, NJ 07083, USA
}

Received June 4,2020; Accepted November 13, 2020

DOI: $10.3892 / \mathrm{ol} .2021 .12469$

\begin{abstract}
Melanoma is a type of highly invasive skin cancer derived from melanocytes with poor prognosis. Vemurafenib (PLX4032) is a clinically approved targeted therapeutic for BRAF mutant melanoma that has a high therapeutic response rate and significantly prolongs the overall survival time of patients with melanoma. Antioxidants have been widely used as supplements for cancer prevention and for decreasing the side effects of cancer therapy. However, antioxidants can also protect cancer cells from oxidative stress and promote cancer growth and progression. The present study aimed to examine the effect of the antioxidants coenzyme Q10 (CoQ10) and $\beta$-carotene on melanoma cell growth and invasiveness and on the cytotoxicity of vemurafenib against both vemurafenib-sensitive (SK-MEL-28) and vemurafenibresistant (A2058) human malignant melanoma cell lines. MTS assay and wound-healing assay demonstrated that CoQ10 alone significantly reduced the viability and migration of melanoma cells, respectively, and synergistically worked with vemurafenib to decrease the viability and migration of human melanoma cells. In contrast, MTS assay and flow cytometry revealed that $\beta$-carotene alone did not affect the viability and apoptosis induction of melanoma cells; however, it inhibited cell migration and invasiveness. Wound-healing and Transwell assay demonstrated that $\beta$-carotene alleviated the cytotoxicity of vemurafenib and mitigated the inhibitory effect of vemurafenib on cell migration and invasion. Both CoQ10 and $\beta$-carotene protected melanoma cells from undergoing apoptosis induced by vemurafenib. Immunoblotting demonstrated that $\beta$-carotene at physiological concentration
\end{abstract}

Correspondence to: Dr Yixin Yang, School of Natural Sciences, College of Science and Technology, Wenzhou Kean University, 88 University Road, Wenzhou, Zhejiang 325035, P.R. China E-mail: yyang@kean.edu

Key words: melanoma, $\beta$-carotene, coenzyme Q10, vemurafenib, Ras-Raf-Mek-Erk intracellular signaling pathway, apoptosis, invasion worked synergistically with vemurafenib to suppress the Ras-Raf-Mek-Erk intracellular signaling pathway. The present study aimed to add to the evidence of the in vitro effects of CoQ10 and $\beta$-carotene on the antimelanoma effects of vemurafenib.

\section{Introduction}

Malignant melanoma is a highly metastatic skin cancer with poor prognosis (1). The incidence rates of melanoma have been growing in all regions of the world (2), where $\sim 287,723$ cases of cutaneous melanoma were newly diagnosed and about 60,712 deaths were caused by melanoma in 2018 (3). In the United States, the estimated number of new cases of melanoma are 100,350 (60,190 men and 40,160 women), accounting for $3.33 \%$ of all new cancer cases, which will result in 6,850 estimated deaths in 2020 (4).

The advent of molecular targeted therapy and immunotherapy has revolutionized the treatment strategy and significantly improved the outcome of patients with melanoma compared with 10 years ago, when the median survival of patients was only about 6 months, and the 5-year survival rate was $<5 \%$ (5). Targeted therapy abolished the abnormal activation of the MAPK pathway caused by hyperactive mutations of the proto-oncogene BRAF (6). In total $\sim 50 \%$ of patients with melanoma harbor $B R A F$ mutations, and $80-90 \% B R A F$ mutations occur at the 600th codon known as BRAFV600E/K/R or BRAFV600 with other amino acid substitutions $(7,8)$. A few BRAF kinase inhibitors (BRAFi) have been developed, of which vemurafenib (PLX4030), dabrafenib and encorafenib targeting BRAFV600E or BRAFV600K were approved for advanced melanoma by the Food and Drug Administration (FDA) (9). Clinical trials have demonstrated that vemurafenib produces as high as an $80 \%$ response rate in BRAFV600E patients with melanoma $(7,10,11)$. The combinations of a BRAF inhibitor and a MEK inhibitor notably increased the overall survival of BRAFV600E patients with melanoma (12). Immunotherapy improves the immune response to melanoma by inhibiting negative immunity modulators (13). The immune checkpoint blockade (ICB) approach targets cytotoxic T lymphocyte-associated antigen 4 and programmed cell death protein 1 and its ligand programmed death ligand 1 which 
suppress antitumor immunity (13). Compared with conventional therapy, molecular targeted therapy and immunotherapy provide multiple more effective treatment options; however, they also present challenges that have yet to be addressed for improving outcomes (13). Single-agent BRAF inhibitor vemurafenib has a high response rate, but has much less optimal durability of response ( $<6$ months) (7). In addition, there are several common side effects associated with vemurafenib including joint pain, rash, photosensitivity dermatitis, fatigue, hair loss and itching $(7,14,15)$. Though BRAFi-MEKi combinations demonstrated a more durable response compared with single-agent BRAF inhibitors, there are also obvious side effects including squamous cell carcinoma, keratoacanthoma, liver enzyme abnormalities and pyrexia (14). ICB inhibitors (ICI) increase the activity of immune response and cause immune-related adverse events (irAEs) in multiple organs including skin, liver, gastrointestinal tract, thyroid and lung (16-20). Severe irAEs are life-threatening and can result in treatment discontinuation $(21,22)$. Therefore, lack of durability of response to BRAF inhibitors, durable response occurring in only $1 / 3$ patients receiving BRAFi/MEKi, resistance to BRAFi/MEKi and systemic toxicity and intolerance of ICI treatment (7) pose pressing needs for developing additional therapeutic regimens to achieve improved management for advanced melanoma.

Previous studies reported that antioxidants are able to inhibit cancer progression (23). Antioxidants can inhibit the initiation of cancer by scavenging free radicals, such as superoxides, hydroxyls and oxides of nitrogen that cause DNA damage and mutations in tumor suppressor genes (24-26). Antioxidants also scavenge the reactive oxygen species, which are believed to promote cell migration and invasion in metastasized cancers (27). Hence, antioxidants have been advocated as a potent and safe supplement for cancer prevention. Antioxidants can also repair normal tissue damage caused by free radicals that are generated by radiotherapy and chemotherapy (28-31). Hence, antioxidants have been widely used to decrease the side effects of cancer therapy $(31,32)$. However, some research has demonstrated that antioxidants can increase cancer risk $(32,33)$. It has been reported that antioxidants increase metastasis of melanoma in mice (34). Antioxidants may protect cancer cells from oxidative stress, thus inhibiting apoptosis and promoting the metastasis of melanoma cells (35). Therefore, there is a heated debate on whether antioxidants can be recommended to patients with cancer, especially for patients who receive free-radical-producing radiotherapy or chemotherapy $(31,32)$. The contradictory results about the effect of antioxidants on the progression of cancers warrants further research on the working mechanisms of antioxidants in cancers (36).

Coenzyme Q-10 (CoQ10) is used by the body system as an endogenous antioxidant and it indicates the oxidative stress level of cells (37). CoQ10 is widely used as a dietary supplement because of its antioxidative property, which has been reported to be beneficial in treating hypertension and congestive heart failure and ameliorating the side effects of chemotherapy $(32,38,39)$. Low blood level of CoQ10 was reported in patients with cancers of breast, lung, prostate, colon, pancreas, kidney, head and neck, and myeloma and lymphoma $(32,40,41)$. Studies have demonstrated that low plasma CoQ10 levels may be an independent prognostic factor for the progression of melanoma and breast cancer $(42,43)$. However, a recent study reported a completely contradictory finding: The serum level of CoQ10 were found to be significantly higher in newly diagnosed and non-intervened patients with breast cancer compared with the healthy control group, suggesting that CoQ10 may offer a growth advantage for breast cancer cells over normal cells (44). CoQ10 was reported to decrease the effectiveness of radiation therapy against small-cell lung cancer due to its antioxidant property that protects cancer cells from the toxicity of free radicals produced by radiation (45). Several studies using CoQ10 as an adjuvant therapy in human subjects reported that CoQ10 presented favorable effects on achieving regression of tumor masses and remission of distant metastasis of breast cancer $(45,46)$. However, all these studies have major design flaws, including the absence of appropriate control groups, patient selection bias and compounding factors such as receiving other supplements or standard cancer treatment $(45,46)$. Hence, it remains difficult to draw a conclusion about any anticancer effect directly related to the intake of CoQ10 (47). The National Cancer Institute states that, as of April 2019, 'No report of a randomized clinical trial of coenzyme $\mathrm{Q}_{10}$ as a treatment for cancer has been published in a peer-reviewed scientific journal' (48). In addition, to the best of our knowledge very little research has been done on the effect of CoQ10 on melanoma. Only one recent study demonstrated that CoQ10 did not affect the viability of some BRAF V600E melanoma cells, such as SK-MEL-28 (49).

$\beta$-carotene has been widely used as a pigment in foods (fats and oil, and infant formula as a source of vitamin A), cosmetics (an additive in cosmetics for tanning and sunscreen) and drugs (such as a prescription drug for treating erythropoetic protoporphyria) and it showed no mutagenicity or cytotoxicity (50). $\beta$-carotene is an antioxidant consisting of polyunsaturated hydrocarbons consisting of 40 carbons and no oxygen (51). It has been reported that $\beta$-carotene inhibits angiogenesis and activation of transcription factors, such as c-fosc and activated transcription factor 2 in mouse melanoma cells (52). An in vivo study demonstrated that $\beta$-carotene inhibited lung metastasis induced by B16 melanoma in mice (53). A large number of epidemiological studies have reported an inverse relationship between the blood level of $\beta$-carotene and lung cancer risk $(54,55)$. The incidence of non-melanocytic skin cancer was inversely related to the serum level of $\beta$-carotene (56). In addition, $\beta$-carotene was found to be photoprotective against UV-induced carcinogenesis (57). However, a study demonstrated that $\beta$-carotene-supplemented semi-defined diets not only provided no photoprotective effect, but also significantly exacerbated UV-induced carcinogenesis (58). In addition, smokers supplemented with $\beta$-carotene demonstrated a significantly higher incidence of lung cancer compared with smokers who were not taking $\beta$-carotene as a supplement $(59,60)$. Epidemiological studies have demonstrated an association between higher incidence of lung cancer and $\beta$-carotene intake $(50,61)$. The effect of $\beta$-carotene on the initiation and development of cancers may be divergent in different cancers (62). To the best of our knowledge no research has been done on the effect of $\beta$-carotene on the proliferation and invasiveness of human malignant melanoma cells. To the best 
of our knowledge the effect of $\beta$-carotene on the cytotoxicity of BRAF inhibitors has not been investigated either.

Since cancer cells perform high-level metabolic activity and suffer from more oxidative stress (63), antioxidants could potentially promote the growth and progression of cancers by mopping up free radicals from cancer cells. In fact, our previous research has demonstrated that antioxidant vitamin $\mathrm{C}$ exerted a stimulatory effect at physiological concentration on the growth and metastasis of human malignant melanoma (64).

In the present study, we hypothesized that the antioxidants CoQ-10 and $\beta$-carotene have an effect on the growth and invasiveness of human malignant melanoma cells. In addition, in a previous study our lab demonstrated that the BRAF kinase inhibitor vemurafenib, an FDA-approved antimelanoma drug, increased the oxidative stress in human malignant melanoma cells (64); thus antioxidants may interfere with the cytotoxic effect of vemurafenib on melanoma cells by scavenging free radicals. Hence, the present study aimed to determine the effect of CoQ-10 and $\beta$-carotene on the growth, migration and invasion and apoptosis induction of human malignant melanoma cell lines, and also on the cytotoxicity of emurafenib on human malignant melanoma cells. The present study aimed to better understand the biological effects and working mechanism of the antioxidants CoQ-10 and $\beta$-carotene on malignant melanoma so that clinicians can decide whether adding antioxidant supplements to the cancer treatment regimen is a viable option.

\section{Materials and methods}

Chemicals. Vemurafenib (PLX4032; cat. no. S1267) was purchased from Selleck Chemicals. CoQ10 (cat. no. C9538) and $\beta$-carotene (cat. no. C9750) were purchased from Sigma-Aldrich; Merck KGaA.

Cells and culture conditions. SK-MEL-28 (PLX sensitive) and A2058 (PLX resistant) human melanoma cell lines were purchased from the American Type Culture Collection (ATCC). SK-MEL-28 and A2058 were cultured in Eagle's Minimum Essential Medium (EMEM; Thermo Fisher Scientific Inc.) and Dulbecco's Modified Eagle's medium (DMEM; Thermo Fisher Scientific Inc.), respectively and were supplemented with $10 \%$ fetal bovine serum (FBS; Thermo Fisher Scientific Inc.) and $0.1 \%$ penicillin/streptomycin (Thermo Fisher Scientific Inc.). Cells were grown at $37^{\circ} \mathrm{C}$ in a humidified atmosphere of $5 \%$ $\mathrm{CO}_{2}$.

MTS assay. SK-MEL-28 and A2058 cells were seeded into 96-well plates (3,000 cells/well) (Costar, Corning Inc.) and incubated for $12 \mathrm{~h}$ to allow the cells to attach. To test the effect of the CoQ10 on cell viability, the cells in the experimental groups were treated with CoQ10 at final concentrations of 1, 5 and $10 \mu \mathrm{M}$, respectively. The cells in control groups were treated with the drug vehicle dimethyl sulfoxide (DMSO) (Fisher Bioreagents; Thermo Fisher Scientific Inc.). To test the efficacy of CoQ10 on the cytotoxicity of PLX4032 against melanoma cell proliferation, the SK-MEL-28 and A2058 cells were treated with PLX4032 at 2 and $20 \mu \mathrm{M}$, respectively, together with CoQ10 at 1,5 and $10 \mu \mathrm{M}$. The cells in the control groups were treated with the drug vehicle dimethyl sulfoxide (DMSO) (Fisher Bioreagents; Thermo Fisher Scientific Inc.).
After incubation for $48 \mathrm{~h}, 10 \mu \mathrm{M}$ MTS (3-(4,5-dimethylthiazol-2-yl)-5-(3-carboxymethoxyphenyl)-2-(4-sulfophenyl)-2H tetrazolium) reagent (Promega Corporation) was added into each well and incubated for $3 \mathrm{~h}$ at $37^{\circ} \mathrm{C}$. The absorbance of solubilized dye was measured by a microplate reader (BioTek Instruments Inc.) at $490 \mathrm{~nm}$. Three independent experiments were performed and the results were reported as means \pm SD.

Wound healing assay. SK-MEL-28 and A2058 cells $\left(2 \times 10^{5}\right)$ were seeded into 12-well plates and incubated for $24 \mathrm{~h}$ until they reached $\sim 90 \%$ confluence. Then the layer of cells was scraped with a $200 \mu 1$ micropipette tip to create a wound. Plates were washed with Hanks' Balanced Salt Solution (HBSS; Sigma-Aldrich; Merck KGaA) and replaced with fresh serum free medium. The assay was performed in 8 groups: i) Group 1 was the control group, which was treated with drug vehicle (DMSO); ii) groups 2, 3, and 4 were treated with CoQ10 or $\beta$-carotene at final concentrations of 1,5 and $10 \mu \mathrm{M}$, respectively; iii) group 5 was treated with $2 \mu \mathrm{M}$ PLX4032 alone; and iv) groups 6, 7, and 8 were treated with PLX4032 at a final concentration of $2 \mu \mathrm{M}$ and CoQ10 or $\beta$-carotene at final concentrations of 1,5 and $10 \mu \mathrm{M}$, respectively. The images of the wounds were captured at 0 and $24 \mathrm{~h}$ under an inverted light microscope (magnification, x100) and the average wound distance was calculated using ImageJ software v.1.53f (National Institutes of Health).

Transwell cell invasion assay. Matrigel-precoated 24-well Transwell inserts (cat. no. 354480; Corning Inc.) were used. A2058 $\left(3 \times 10^{4}\right)$ cells were resuspended in $200 \mu 1$ serum-free Eagle's minimum essential medium in the upper chamber of a 24-well plate. Culture medium (700 $\mu \mathrm{l})$ containing $20 \%$ fetal bovine serum was applied to the lower chamber. The assay was performed in 8 groups: i) Group 1 was the control group, which was treated with drug vehicle (DMSO); ii) groups 2, 3 , and 4 were treated with $\beta$-carotene at final concentrations of 1,5 and $10 \mu \mathrm{M}$, respectively; iii) groups 5, 6, and 7 were treated with PLX4032 at a final concentration of $2 \mu \mathrm{M}$ and $\beta$-carotene at final concentrations of 1,5 , and $10 \mu \mathrm{M}$, respectively; and iv) group 8 was treated with $2 \mu \mathrm{M}$ PLX4032 alone. After incubation for $18 \mathrm{~h}$ at $37^{\circ} \mathrm{C}$ in a $5 \% \mathrm{CO}_{2}$ incubator, the cells were fixed using $3 \%$ formaldehyde in PBS for $10 \mathrm{~min}$ at room temperature and stained by Giemsa stain for $10 \mathrm{~min}$ at room temperature. Non-migrated cells were scraped off using cotton swabs and migrated cells were counted under the inverted light microscope (magnification, x100).

Apoptosis analysis. Apoptosis was examined using an Annexin V-FITC-propidium iodide (PI) dual staining kit (BioLegend Inc.) followed by flow cytometry analysis according to the manufacturer's instructions. The assay was performed in 8 groups: i) Group 1 was the control group which was treated with drug vehicle (DMSO); ii) groups 2, 3, and 4 were treated with CoQ10 at final concentrations of 1,5 and $10 \mu \mathrm{M}$, respectively; iii) groups 5, 6, and 7 were treated with PLX4032 at a final concentration of $2 \mu \mathrm{M}$ and Coenzyme Q10 at final concentrations of 1,5 and $10 \mu \mathrm{M}$, respectively; and iv) group 8 was treated with $2 \mu \mathrm{M}$ PLX4032 alone. After 24 h, A2058 and SK-MEL-28 were harvested by trypsinization, washed with ice-cold cell staining buffer (Biolegend Inc.), and then 
A

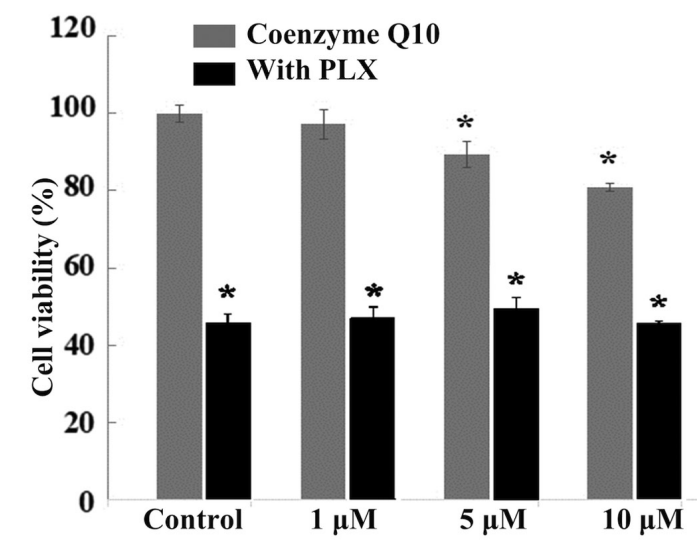

C

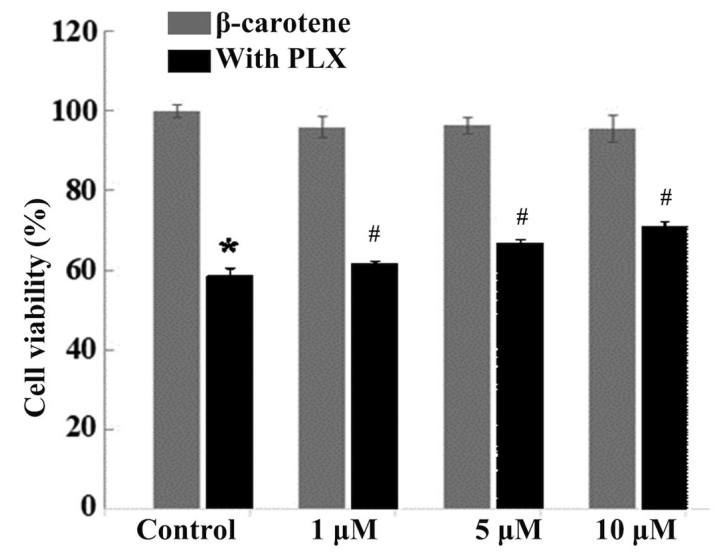

B

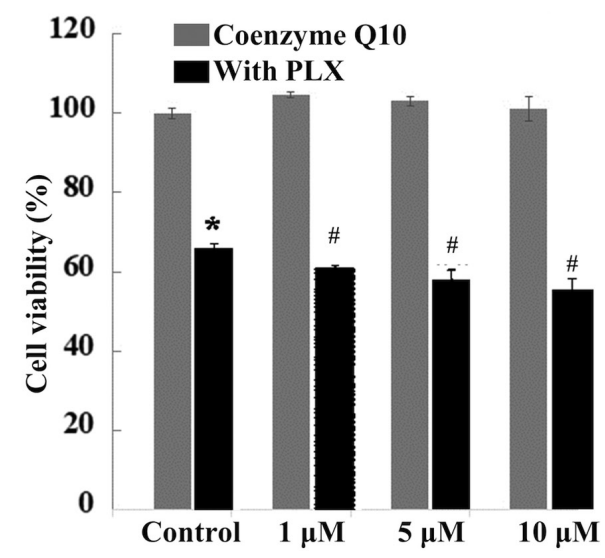

D

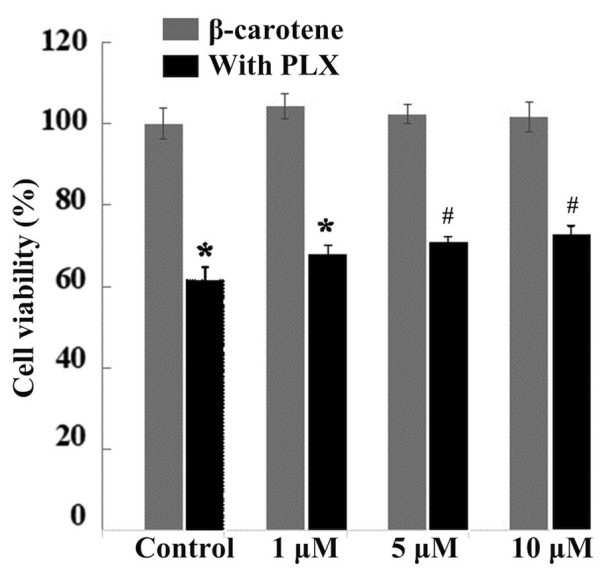

Figure 1. CoQ10 and $\beta$-carotene alleviate the cytotoxicity of PLX against melanoma cells. (A and B) Effects of CoQ10 and (C and D) $\beta$-carotene on the cell viability of SK-MEL-28 and A2058 melanoma cells and the effect of these 2 antioxidants on the cytotoxicity of PLX4032 against SK-MEL-28 and A2058 melanoma cells were determined by the MTS assay after $48 \mathrm{~h}$ of treatment. Each experiment was repeated three times with quadruplicate reactions in each treatment. ${ }^{*} \mathrm{P}<0.05$, control group vs. treatment group; ${ }^{*} \mathrm{P}<0.05$, PLX alone group vs. combined treatment groups (PLX and CoQ10 group or PLX and $\beta$-carotene group). CoQ10, coenzyme Q10; PLX, vemurafenib.

resuspended in the binding buffer (BioLegend Inc.) at a density of $1 \times 10^{6}$ cells $/ \mathrm{ml}$. Cell suspension was stained with Annexin V-FITC and PI and analyzed by the Accuri C6 Flow Cytometer System (BD Biosciences). Both early and late stages of apoptotic cells were counted using associated software CytExpert v.2.1 (Beckman Coulter, Inc.).

Western blotting. After a 48 h treatment, A2058 cells were trypsinized and washed 3 times with PBS and then lysed in a lysis buffer for $30 \mathrm{~min}$ at $4^{\circ} \mathrm{C}$. The proteins were extracted in the supernatant after centrifugation at 14,000 $\mathrm{g}$ for $20 \mathrm{~min}$ at $4^{\circ} \mathrm{C}$ and the concentration of protein was detected using Bio-Rad protein assay reagent (Bio-Rad Laboratories Inc.). After determining the concentrations of proteins with the BCA assay, the proteins $(20 \mu \mathrm{g} /$ lane $)$ were mixed with a Laemmli sample buffer (Bio-Rad Laboratories Inc.) with 5\% 2-Mercapto-ethanol ( $\beta$-ME) (Sigma-Aldrich; Merck KGaA) at the ratio of 1:1 and the mixture was boiled for $10 \mathrm{~min}$ before being electrophoresed on an 4-12\% SDS-PAGE gel (Bio-Rad Laboratories Inc.). The protein was transferred to a nitrocellulose membrane at $350 \mathrm{~mA}$ for $1 \mathrm{~h}$ in the transfer buffer. The membrane was blocked with $5 \%$ non-fat milk in TBST $(0.1 \%$ Tween) for $2 \mathrm{~h}$ at room temperature with shaking. The membrane was then rinsed 3 times with TBST, and subsequently immunoblotted with primary antibodies for rabbit anti-GAPDH (1:1,000; cat. no. 5174), anti-phospho-P44/42 MAPK (1:1,000 cat. no. 4370), anti-total P44/42 MAPK (1:1,000; cat. no. 4695), anti-phospho-BRAF (1:1,000; cat. no. 2696) and anti-total BRAF (1:1,000; cat. no. 14814) (all antibodies were from Cell Signaling Technology Inc.) at $4^{\circ} \mathrm{C}$ overnight. Signals were developed by incubating with the horse radish peroxidase (HRP)-linked secondary antibody (1:1,000; cat. no. 32935; Cell signaling Technology Inc.) for $2 \mathrm{~h}$ at room temperature. GAPDH was used as the internal loading control. Subsequently, development was performed using the Clarity $^{\mathrm{TM}}$ Western ECL Substrate (Bio-Rad Laboratories Inc.) for $5 \mathrm{~min}$. The intensity of the signals was determined by the FluorChem ${ }^{\mathrm{TM}}$ E system (Protein Simple). ImageJ v.1.53f (National Institutes of Health) was used for densitometry.

Statistical analysis. All values are represented as mean \pm standard deviation (SD) from at least three independent experiments, and were subjected to one-way analysis of variance (ANOVA) and compared by the post hoc Tukey's HSD test using SAS University edition (SAS Institute Inc.). $\mathrm{P}<0.05$ was considered to indicate a statistically significant difference. 


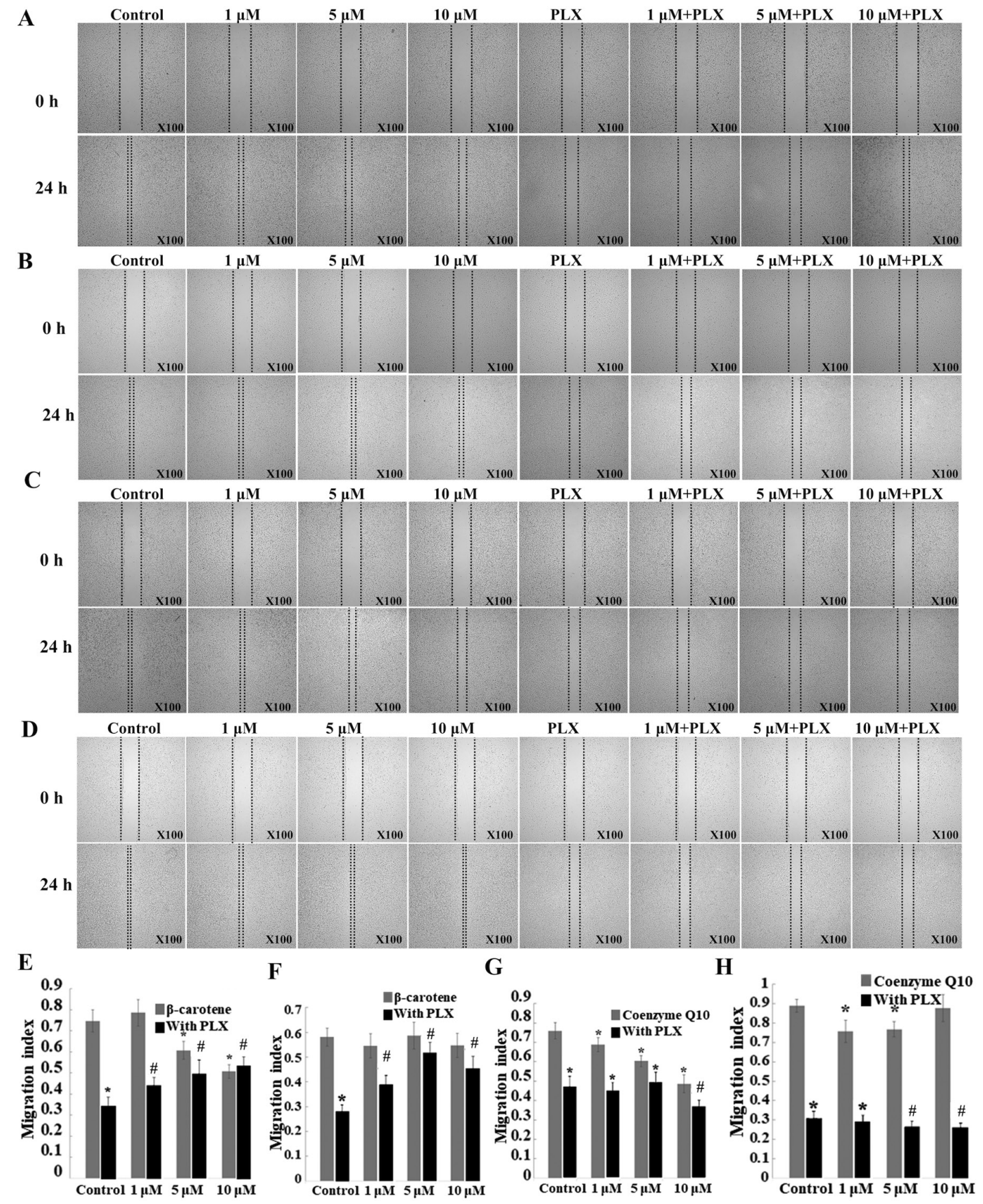

Figure 2. CoQ10 and $\beta$-carotene inhibit melanoma cell migration, but display different effects on the migration inhibition caused by PLX. Cells were grown to confluence and the 'wound' was scraped with a $200 \mu 1$ pipette tip. (A) Representative images of the effect of $\beta$-carotene on cell migration and on the inhibitory effect of PLX on cell migration of (A) SK-MEL-28 and (B) A2058 melanoma cells. (C) Representative images of the effect of CoQ10 on cell migration and on the inhibitory effect of PLX on cell migration of (C) SK-MEL-28 and (D) A2058 melanoma cells. (E) Quantification of migration index of A. (F) Quantification of migration index of B. (G) Quantification of migration index of C. (H) Quantification of migration index of D. " $\mathrm{P}<0.05$, control group vs. treatment group; ${ }^{\#} \mathrm{P}<0.05$, PLX alone group vs. combined treatment groups (PLX and CoQ10 group or PLX and $\beta$-carotene group). CoQ10, coenzyme Q10; PLX, vemurafenib.

\section{Results}

CoQ10 displays cytotoxicity against the sensitive melanoma cell line and $\beta$-carotene alleviates the cytotoxicity of PLX against melanoma cells. MTS assay was used to determine the cytotoxic effect of CoQ10 and $\beta$-carotene in 2 malignant melanoma cell lines: SK-MEL-28 and A2058. In the SK-MEL-28 cell line, which is vemurafenib sensitive, CoQ10 decreased the cell viability and displayed cytotoxicity at 5 and $10 \mu \mathrm{M}$, but did not affect the cytotoxicity of PLX
(Fig. 1A). In A2058, which is a vemurafenib-resistant cell line, CoQ10 did not display cytotoxicity (Fig. 1B). However, CoQ10 increased the cytotoxicity of PLX at 1,5 and $10 \mu \mathrm{M}$ (Fig. 1B). In both SK-MEL-28 and A2058 cell lines, $\beta$-carotene did not display cytotoxicity (Fig. $1 \mathrm{C}$ and D). However, $\beta$-carotene alleviated the cytotoxicity of PLX in both cell lines (Fig. 1C and D).

CoQ10 and $\beta$-carotene both inhibit cell migration, but display different effects on the inhibition of migration of melanoma 
A

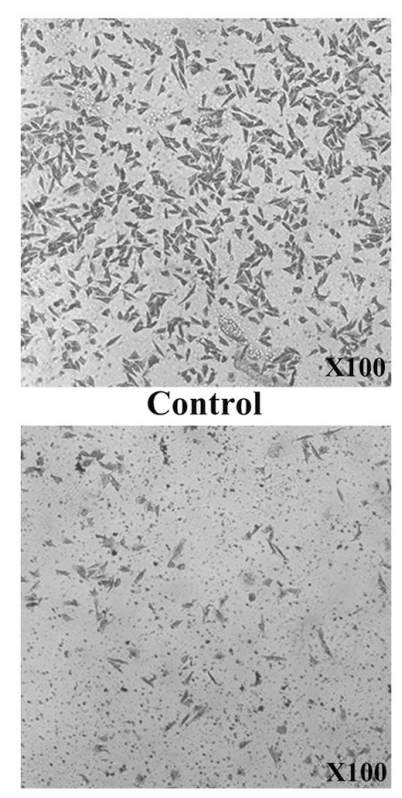

PLX

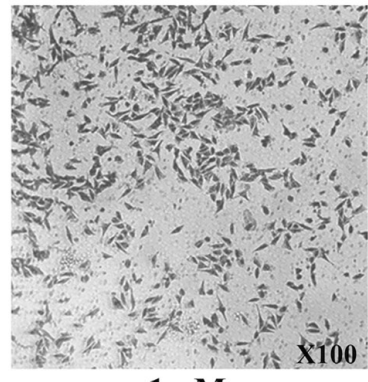

$1 \mu \mathbf{M}$

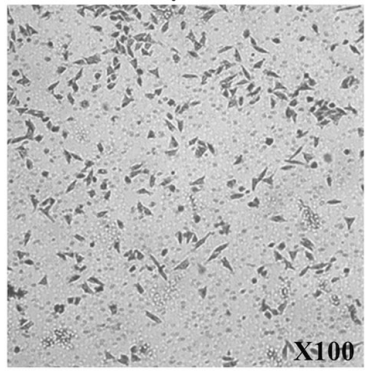

$1 \mu \mathrm{M}+\mathbf{P L X}$

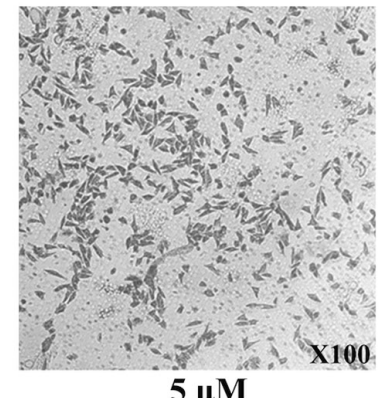

$5 \mu \mathrm{M}$

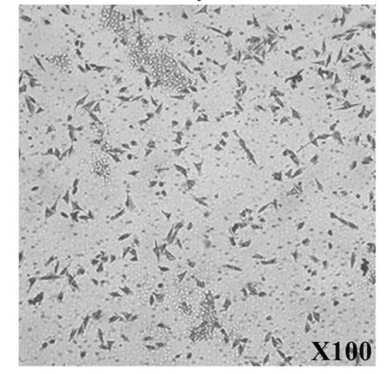

$5 \mu \mathrm{M}+\mathrm{PLX}$

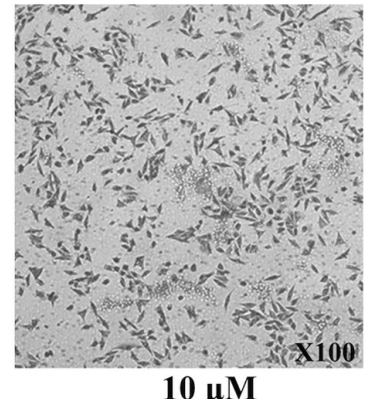

$10 \mu \mathrm{M}$

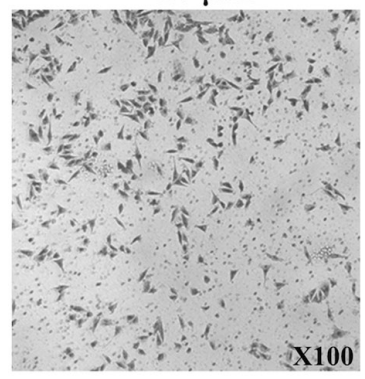

$10 \mu \mathrm{M}+\mathbf{P L X}$

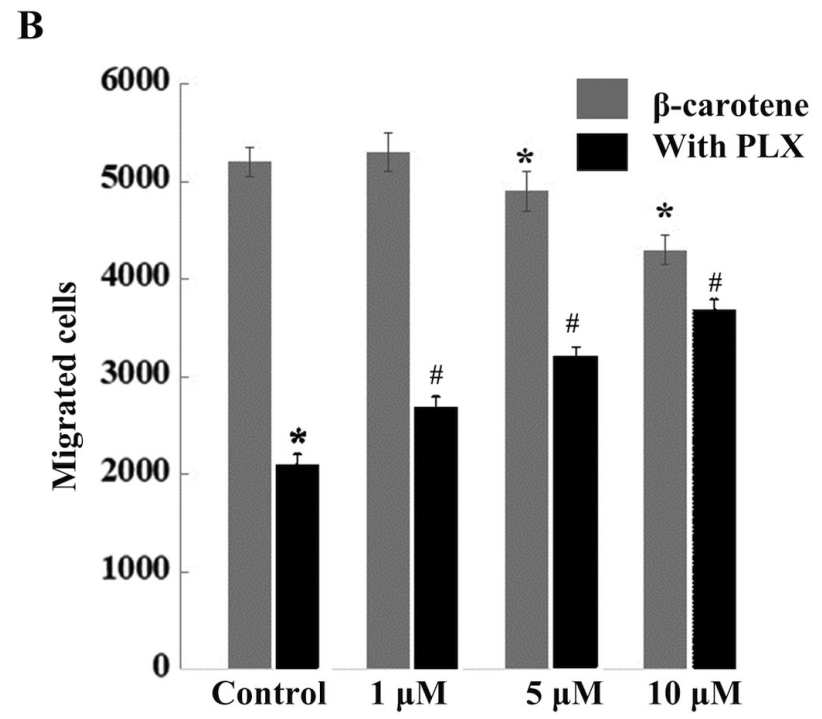

Figure 3. $\beta$-carotene inhibits cell invasion and alleviates the inhibitory effect of PLX on cell invasion. (A) Representative microscopic images of migrated A2058 cells in migration/invasion assays demonstrated the inhibitory effect of $\beta$-carotene alone, and PLX together with $\beta$-carotene. (B) Migrated cell numbers in the control group and different treatment groups. ${ }^{*} \mathrm{P}<0.05$, control group vs. treatment group; $\mathrm{P}<0.05$, PLX alone group vs. combined treatment groups (PLX and $\beta$-carotene group). CoQ10, coenzyme Q10; PLX, vemurafenib.

cells caused by PLX4032. SK-MEL-28 and A2058 migration was examined using the wound healing assay. $\beta$-carotene inhibited the migration of SK-MEL-28 cells (Fig. 2A and E), but showed no effect on A2058 cells (Fig. 2B and F). Notably, $\beta$-carotene alleviated the inhibitory effect of PLX on the migration of both SK-MEL-28 (Fig. 2A and E) and A2058 cells (Fig. 2B and F). CoQ10 inhibited the migration of both SK-MEL-28 (Fig. 2C and G) and A2058 (Fig. 2D and H) cells. In contrast to $\beta$-carotene, CoQ10 at $10 \mu \mathrm{M}$ enhanced the inhibition of SK-MEL-28 cell migration by PLX (Fig. 2C and G), and CoQ10 at 5 and $10 \mu \mathrm{M}$ enhanced the inhibition of A2058 cell migration by PLX (Fig. 2D and $\mathrm{H}$ ). $\beta$-carotene inhibits cell invasion, but alleviates the inhibitory effect of PLX on cell invasion. Since it was reported that $\beta$-carotene inhibited lung metastasis of murine melanoma in vivo (53) and inhibited migration and invasion of human hepatocarcinoma cells in vitro (65), based on these findings the present study examined the effects of $\beta$-carotene on the invasive ability of A2058 human melanoma cells and on the inhibitory effect of PLX4032 on cell invasion using a Matrigel-coated Transwell cell invasion assay. $\beta$-carotene alone at 5 and $10 \mu \mathrm{M}$ significantly decreased A2058 cell invasion across the cell-permeable microporous membrane by 6 and 17\%, respectively (Fig. 3A and B). Notably, $\beta$-carotene 

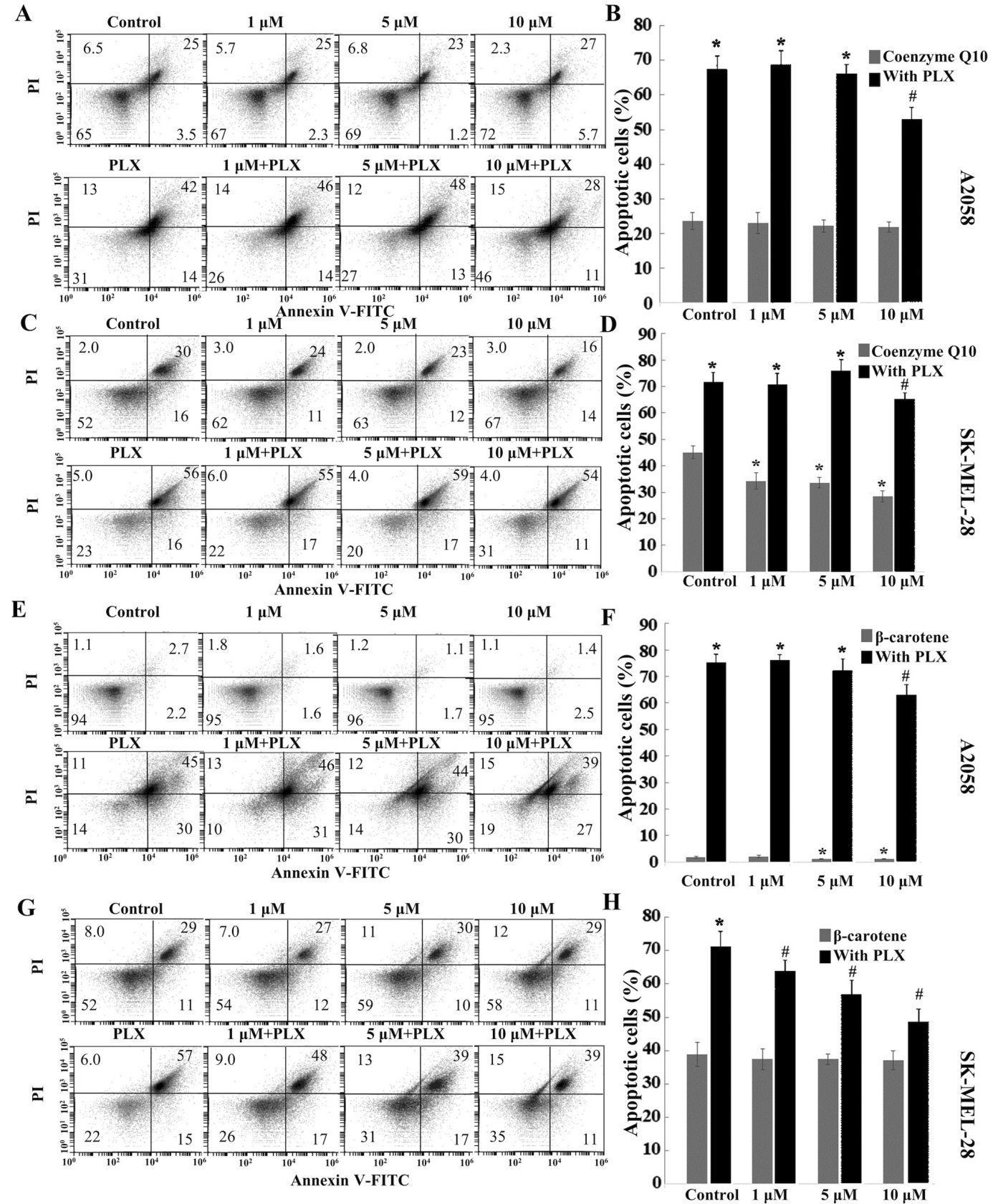

Figure 4. CoQ10 and $\beta$-carotene protect cells from apoptosis induced by PLX. (A) Apoptosis of A2058 cell treated with coenzyme Q10 alone, PLX alone, a combination of PLX with coenzyme Q10, or DMSO vehicle; (B) Quantification of apoptosis rate. (C) Apoptosis of SK-MEL-28 cells treated with coenzyme Q10 alone, PLX alone, a combination of PLX with coenzyme Q10, or DMSO vehicle. (D) Quantification of apoptosis rate of panel C. (E) Apoptosis of A2058 cell treated with $\beta$-carotene alone, PLX alone, a combination of PLX with $\beta$-carotene, or DMSO vehicle. (F) Quantification of apoptosis rate of panel E. (G) Apoptosis of SK-MEL-28 cells treated with $\beta$-carotene alone, PLX alone, a combination of PLX with $\beta$-carotene, or DMSO vehicle. (H) Quantification of apoptosis rate shown in panel G. ${ }^{*} \mathrm{P}<0.05$, control group vs. treatment group; ${ }^{\text {}} \mathrm{P}<0.05$, PLX alone group vs. combined treatment groups (PLX and CoQ10 group or PLX and $\beta$-carotene group). PLX, vemurafenib; PI, propidium iodide.

alleviated the inhibitory effect of PLX on A2058 melanoma cell invasion in a dose-dependent manner (Fig. 3A and B).

CoQ10 and $\beta$-carotene inhibit the apoptosis induced by PLX in melanoma cells. To determine whether CoQ10 and $\beta$-carotene induce apoptosis and affect apoptosis induced by PLX, SK-MEL-28 and A2058 cells were treated with CoQ10 or $\beta$-carotene alone, PLX alone, the combination of PLX and CoQ10, or a combination of PLX and $\beta$-carotene. CoQ10 at $10 \mu \mathrm{M}$ inhibited the apoptosis induced by PLX in A2058 (Fig. 4A and B) and SK-MEL-28 cells (Fig. 4C and D).
Notably, CoQ10 alone inhibited the apoptosis in SK-MEL-28 cells (Fig. 4C and D). Similarly, $\beta$-carotene at $10 \mu \mathrm{M}$ protected A2058 (Fig. 4E and F) and SK-MEL-28 (Fig. 4G and H) from apoptosis induced by PLX. However, $\beta$-carotene alone did not inhibit the apoptosis in SK-MEL-28 cells (Fig. 4G and H).

$\beta$-carotene works synergistically with PLX to suppress the Ras-Raf-Mek-Erk pathway. Since the inhibitory effect of CoQ10 on the signaling pathway has been more established, the present study examined the effect of $\beta$-carotene on the Ras-Raf-Mek-Erk signaling pathway. Ras-Raf-Mek-Erk is an 
A

DMSO

PLX

$\beta$-carotene

$\overline{0 \mu M \quad 1 \mu M \quad 5 \mu M \quad 10} \mu M \quad \overline{1 \mu M \quad 5 \mu M 10 \mu M \quad 0 \mu M}$

$\begin{array}{llllllll}1.0 & 0.93 & 1.0 & 0.95 & 0.34 & 0.47 & 0.55 & 0.83\end{array}$

Phospho-Braf
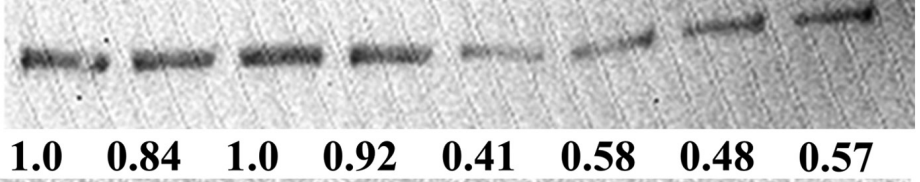

Phospho-Erk

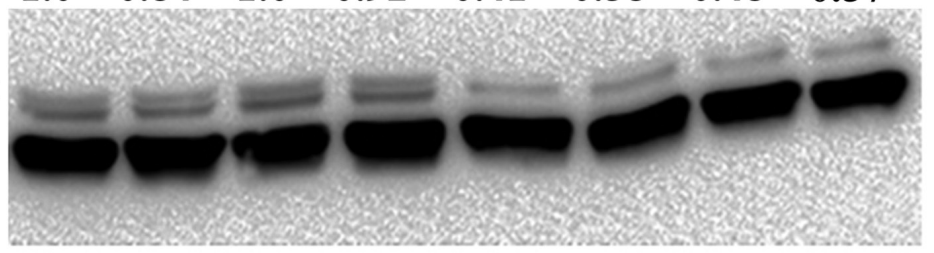

GAPDH

B

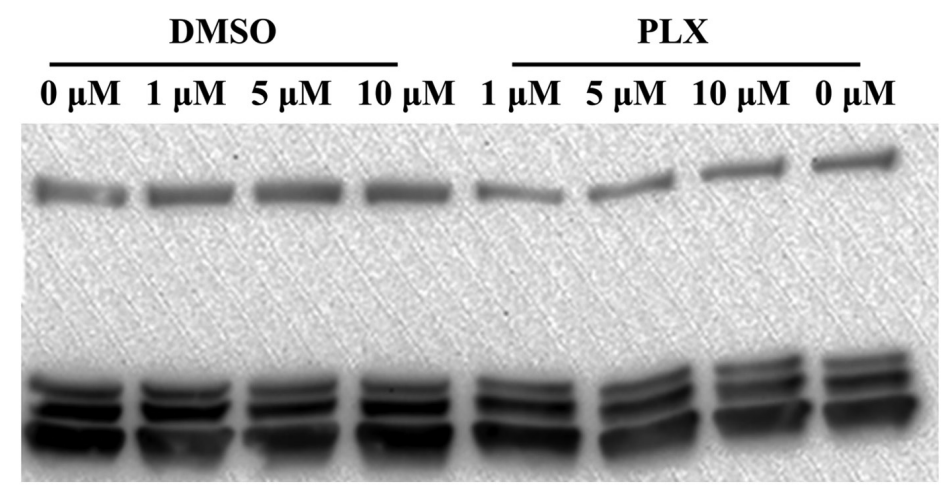

Figure 5. $\beta$-carotene works synergistically with PLX 4032 to suppress the Ras-Raf-Mek-Erk pathway. A2058 cells were treated with $\beta$-carotene at concentrations of $0,1,5$ and $10 \mu \mathrm{M}$ in absence or absence of PLX $4032(2 \mu \mathrm{M})$, and the expression levels of (A) activated form of Braf (phospho-Braf) and Erk (phosphor-Erk) and (B) non-activated Braf and Erk were analyzed by western blotting. The densitometry values shown in the figure correspond to the ratio of phospho/total protein.

important intracellular cell growth signaling pathway and serves critical roles in cancer initiation and development (66). $\beta$-carotene was found in the present study to inhibit cell migration and migration/invasion, which are regulated by the Ras-Raf-Mek-Erk pathway (Fig. 5). In addition, $\beta$-carotene affects the cytotoxicity of veramufenib (Fig. 5), which is a BRAF inhibitor. Based on these findings the present study investigated the effect of $\beta$-carotene on activation of the Ras-Raf-Mek-Erk signaling pathway. A2058 cells, which harbor a BRAF activating mutation and are melanoma resistant, were treated with $\beta$-carotene alone, PLX alone, the combination of PLX and $\beta$-carotene, and DMSO vehicle. After $48 \mathrm{~h}$ incubation, western blotting demonstrated that $\beta$-carotene had no effect on BRAF or ERK expression (Fig. 5A and B), indicating that $\beta$-carotene alone did not have an effect on the activation of this pathway. However, $\beta$-carotene at a physiological concentration $(1 \mu \mathrm{M})$ synergistically worked with PLX to suppress the activation of BRAF and the downstream Erk1/2 (Fig. 5A and B).

\section{Discussion}

Antioxidants are molecules that scavenge free radicals including ROS, and thus, relieve the oxidative stress of cells (67). An insufficient level of antioxidants causes increased oxidative stress that is closely involved in aging and numerous diseases including cancers (67). Specifically, antioxidants affect tumor initiation and development through quenching carcinogen activation, reducing DNA oxidation, switching of growth-related signal transduction pathways, inducing cell cycle arrest and inhibiting cell migration and invasion (68). Hence, it is generally believed that taking antioxidant supplementation is beneficial for the prevention and treatment of cancers (69). Numerous research articles advocated antioxidants as cancer fighters (70-72) and reported that high doses of dietary antioxidants often inhibit the growth of cancer cells without affecting the growth of normal cells $(71,72)$. A population-based prospective cohort study demonstrated that the use of antioxidants vitamin $\mathrm{E}$ and $\mathrm{C}$ in the first six months of diagnosis significantly reduced the mortality and recurrence of invasive breast cancer (73). Antioxidants have been used as beneficial adjuncts to the conventional cancer therapy in clinical studies $(74,75)$. However, increasing evidence has demonstrated that antioxidants are not necessarily beneficial in combating cancers. For example, it has been reported that antioxidants stimulated cell growth in parotid acinar cells (76). In addition, the use of antioxidants vitamin $E$ and $\beta$-carotene concurrently with radiotherapy in head and neck cancer patients significantly increased recurrence and cancer-specific mortality (25). Hence, whether the use of antioxidants in 
cancer prevention and treatment is recommendable and whether antioxidants exert a synergistic or antagonistic effect with chemotherapy deserves close scrutiny. The present study examined the effects of two antioxidants, CoQ10 and $\beta$-carotene, on the viability, migration, invasion, apoptosis, and intracellular signaling of human malignant melanoma cells. As our previous study demonstrated that vemurafenib increased the oxidative stress in human malignant melanoma cells (33), the present study hypothesized that CoQ10 and $\beta$-carotene can affect the cytotoxicity of vemurafenib by modulating oxidative stress and its downstream effects. The present study used a venurafenib-resistant melanoma cell line (A2058) to examine whether the combination of antioxidants with vemurafenib can produce stronger cytotoxicity against resistant cell lines.

CoQ10 is a free radical-scavenging antioxidant due to its capacity to act as both a two-electron carrier and a one-electron carrier (68). Since no large-scale strictly-controlled clinical trials of coenzyme Q10 in cancer treatment have been done, the association between coenzyme Q10 and cancers is not well understood (47). However, the American Cancer Society has concluded that ' $\mathrm{CoQ}{ }_{10}$ may reduce the effectiveness of chemo and radiation therapy, so most oncologists would recommend avoiding it during cancer treatment' (77). Research has demonstrated that an imbalance in the antioxidant system can be detected in melanoma cells and in a percentage of normal melanocytes from patients with melanoma (78), and low plasma level of CoQ10 may be a prognostic factor for melanoma progression (42). Due to the low concentration of coenzyme Q10 in melanoma cell lines, and in sera of patients with melanoma, CoQ10 was used in combination with an optimized dose of recombinant interferon $\alpha-2 b$ in a 3 -year trial, which demonstrated that this combination significantly reduced the recurrence rate (79). A recent study reported that the mean of maximum plasma concentration in a group of healthy volunteers who received $100 \mathrm{mg}$ (Bid) of CoQ10 was $1501 \mu \mathrm{g} / \mathrm{l}(1.8 \mu \mathrm{M})(80)$. It is also known that $300 \mathrm{mg}$ per day is a common dosage of commercial products of coenzyme Q10 (81). Published research used coenzyme Q10 at concentrations from 5-60 $\mu \mathrm{M}(64,82,83)$. The present study used CoQ10 at concentrations of 1,5 and $10 \mu \mathrm{M}$ that are achievable in the plasma of CoQ10 supplement-consuming individuals.

Hong et al (49) reported that coenzyme Q10 did not suppress the BRAF V600E melanoma cell line. However, by examining the effect of coenzyme Q10 on the viability of two human malignant melanoma cell lines in the present study, it was found that CoQ10 significantly reduced the viability of SK-MEL-28 cells, which is a PLX-sensitive melanoma cell line. In the present study for the A2058 cell line, which is a PLX-resistant cell line, CoQ10 alone did not display cytotoxicity. However, it increased the cytotoxicity of the FDA-approved Braf inhibitor vemurafenib. The findings of the present study support the notion that CoQ10 can potentially be a good adjunct to targeted chemotherapy or immunotherapy against melanoma.

The present study also demonstrated that CoQ10 significantly reduced the migration of both SK-MEL-28 and A2058 cells. To the best of our knowledge, the present study is the first to have reported the inhibitory effect of CoQ10 on the migration of cancer cells. It has been previously reported that a functional dietary supplement containing CoQ10 branched-chain amino acids and L-carnitine completely inhibited the metastasis of melanoma to the lung (84). In addition, exogenous CoQ10 reduced matrix metalloproteinases 2 (MMP-2) activity in a breast cancer cell line (MCF-7), suggesting the importance of coenzyme Q10 on cell invasion effector molecules (85). Hence, CoQ10 may inhibit metastasis of melanoma by directly inhibiting cell migration and reducing MMP-2 activity that helps melanoma cells break through the intracellular matrix facilitating metastasis.

The present study also examined the effect of CoQ10 on the induction of apoptosis that serves vital roles in tumor survival and progression. The present study demonstrated that CoQ10 significantly reduced the percentage of apoptotic cells. In addition, CoQ10 alleviated the apoptosis induced by vemurafenib in both A2058 and SK-MEL-28 cells. This finding is in concert with previous reports that demonstrated that CoQ10 protects cells from undergoing apoptosis induced by cytotoxic chemicals in both cancerous (86) and non-cancerous cells (87). Therefore, apoptosis induction is not a mechanism by which CoQ10 exerts its cytotoxic effect against melanoma cell lines. In addition, in the present study CoQ10 potentially mitigated the cytotoxic effect of chemotherapeutic agents that kill cancer cells primarily through inducing apoptosis.

The association of $\beta$-carotene with cancers is a hot focus of research. A trial demonstrated that neither $\beta$-carotene nor vitamin A supplement had any beneficial effect in preventing cancer including melanoma (61). Instead, increased risk of lung and prostate cancers was found in participants who consumed $\beta$-carotene and had lung irritation from cigarette smoking or asbestos exposure (88). Another study demonstrated that in addition to lung cancer, the incidence of gastric cancers was also significantly increased in individuals who took 20-30mg $\beta$-carotene a day (89). However, other studies have reported some anticancer activities of $\beta$-carotene. For example, $\beta$-carotene at a low physiological concentration inhibited cell viability and induced apoptosis in human breast cancer MCF-7 cell line $(90,91)$. $\beta$-carotene also inhibited lung metastasis induced by melanoma cells in mice (53). In addition, $\beta$-carotene inhibited angiogenesis and the activation of transcription factors in mouse melanoma cells (52). The present study aimed to further characterize the effect of $\beta$-carotene on human malignant melanoma cells. In the present study, $\beta$-carotene did not exhibit inhibitory or promoting effects on the viability of SK-MEL-28 and A2058 melanoma cells. However, in both cell lines, $\beta$-carotene mitigated the cytotoxic effect of vemurafenib, suggesting that the intake of $\beta$-carotene may decrease the therapeutic effect of vemurafenib. $\beta$-carotene significantly reduced cell migration and invasion, which was indicated by the ability of cells to move across the microporous membrane as seen in the transwell cell migration/invasion assay (Fig. 3). These findings are consistent with a published work, which reported that $\beta$-carotene inhibited the migration of human umbilical vein endothelial cells by downregulating the expression of MMP-2 and MMP-9, and by upregulating the expression of tissue inhibitors of metalloproteinase (TIMP)-1 and TIMP-2 (52). The present study supports the notion that $\beta$-carotene may inhibit the metastasis of melanoma, which is in concert with a previous report that demonstrated that $\beta$-carotene inhibited the metastasis of mouse melanoma cells 
to the lung (53). However, as in the present study $\beta$-carotene significantly alleviated the inhibition of cell migration caused by vemurafenib in both the SK-MEL-28 and A2058 cell lines, which raises a concern that $\beta$-carotene may suppress the anti-metastatic effect of vemurafenib.

$\beta$-carotene was reported to induce apoptosis by decreasing the expression of the anti-apoptotic proteins Bcl-2 and Poly (ADP-ribose) polymerase and the survival protein NF- $\kappa \mathrm{B}$ in breast cancer cells (90). Contrary to the aforementioned study, the present study demonstrated that $\beta$-carotene did not induce apoptosis in human malignant melanoma cell lines, suggesting that the apoptosis induction of $\beta$-carotene may be specific to particular types of cancers. In addition, similar to the effect of $\beta$-carotene on the inhibitory effect of vemurafenib on cell viability and cell migration/invasion, $\beta$-carotene protected cells from apoptosis induction in both the SK-MEL-28 and A2058 cells induced by vemurafenib in the present study. This finding also suggests that $\beta$-carotene may decrease the antimelanoma effect of vemurafenib.

Ras-Raf-Mek-Erk is a vital cell-signaling pathway that regulates cell cycle entry and drives cell proliferation. Since A2058 cells harbor BRAF activating mutations (92), the present study examined the effect of $\beta$-carotene on the activation of the Ras-Raf-Mek-Erk signaling pathway. The present study revealed that $\beta$-carotene alone did not have effect on the activation of this pathway, however, $\beta$-carotene at physiological concentration $(1 \mu \mathrm{M})$ synergistically worked with vemurafenib to suppress the activation of BRAF and the downstream Erk1/2. This result is consistent with another study which demonstrated that $\beta$-carotene inhibited Erk1/2 in breast cancer MCF-7 cells (90). It has been reported that CoQ10 inhibited activation of Ras-Raf-Mek-Erk signaling pathway in various cell types, such as fibroblasts and endothelial cells (93-95). Since the inhibitory effect of CoQ10 on the signaling pathway has been more established, the present study examined the effect of CoQ10 on the Ras-Raf-Mek-Erk signaling pathway.

It has been reported that $\mathrm{CD} 8^{+}$tumor-infiltrating lymphocytes (TILs) contributes to the development of BRAFi resistance (96). The prolonged exposure to BRAFi causes melanoma cells to become non-proliferative and non-differentiated cells that are less responsive to TILs (97). Since no study has demonstrated to the best of our knowledge that CoQ10 or $\beta$-carotene regulate the antigen recognizing activities of TILs, the effect of antioxidants on $\mathrm{CD}^{+} \mathrm{T}$ cell-mediated BRAFi resistance were not investigated in the present study.

Antioxidants serve a significant role in the antiinflammatory mechanism (67). As oxidative stress leads to inflammatory response, antioxidants can reduce inflammation by alleviating the oxidative stress (98). Antioxidants, such as CoQ10, suppress inflammation, ameliorate the autoimmune response and modulate immune cells including Th17 (99). It was recently reported that antioxidants can improve adoptive $\mathrm{T}$ cell transfer immunotherapy against tumors by regulating $\mathrm{CD}^{+} \mathrm{T}$ memory stem cell formation (100). Hence, the effect of CoQ10 on immunotherapy warrants further study.

The present study had a limitation that it was an in vitro study. In vitro assays can contribute to knowledge of direct effects of CoQ10 and $\beta$-carotene on melanoma cells and to elucidate the working mechanisms. However, the actual biological effects of CoQ10 and $\beta$-carotene need to verified in animal models. Numerous previous studies using coenzyme Q10 as an adjuvant therapy in human subjects had major flaws, including taking other supplements that confounded the effect of consumption of CoQ10 or $\beta$-carotene $(101,102)$. Nevertheless, the synergistic effect of CoQ10 and vemurafenib and the antagonist effect of $\beta$-carotene and vemurafenib need to be examined in mouse xenograft models in future studies. In addition, since the cardiocytotoxicity of combination of $\mathrm{BRAFi} / \mathrm{MEKi}$ has become a growing problem in the treatment of metastatic melanoma (103), and CoQ10 is protective against cardiotoxicity and improves tolerability of cancer therapeutics (47), the effect of the combination of CoQ10 and BRAFi/MEKi on melanoma should be the aim of future studies. In summary, in the present study regardless of displaying its ability to protect melanoma cells from apoptosis induction, CoQ10 demonstrated an inhibitory effect on cell proliferation and migration/invasion when used individually or in combination with vemurafenib. The cytotoxic effects of CoQ10 make it a good candidate adjunct for existing standard therapies for melanoma. In contrast, $\beta$-carotene suppressed the anti-melanoma effects (antiproliferative effect, antiinvasive effect and apoptosis-inducing effect) of vemurafenib, suggesting that caution should be taken when $\beta$-carotene is used concurrently with anti-melanoma BRAF inhibitors including vemurafenib.

\section{Acknowledgements}

Not applicable.

\section{Funding}

The current study was supported by a grant from the Zhejiang International Science and Technology Cooperation Center Fund provided by Wenzhou Kean University.

\section{Availability of data and materials}

The datasets used and analyzed during the current study are available from the corresponding author on reasonable request.

\section{Authors' contributions}

YY designed and directed the project. $\mathrm{CH}$ performed the experiments. YH and PL performed the experiments. $\mathrm{CH}$ wrote the manuscript. YY revised the manuscript for important intellectual content. All authors read and approved the final manuscript.

\section{Ethics approval and consent to participate}

Not applicable.

\section{Patient consent for publication}

Not applicable.

\section{Competing interests}

The authors declare that they have no competing interests. 


\section{References}

1. Sandru A, Voinea S, Panaitescu E and Blidaru A: Survival rates of patients with metastatic malignant melanoma. J Med Life 7: 572-576, 2014

2. Karimkhani C, Green AC, Nijsten T, Weinstock MA, Dellavalle RP, Naghavi M and Fitzmaurice C: The global burden of melanoma: Results from the global burden of disease study 2015. Br J Dermatol 177: 134-140, 2017.

3. Schadendorf D, van Akkooi ACJ, Berking C, Griewank KG Gutzmer R, Hauschild A, Stang A, Roesch A and Ugurel S: Melanoma. Lancet 392: 971-984, 2018.

4. Siegel RL, Miller KD and Jemal A: Cancer statistics, 2020. CA Cancer J Clin 70: 7-30, 2020.

5. Boniol M, Autier P, Boyle P and Gandini S: Cutaneous melanoma attributable to sunbed use: Systematic review and meta-analysis. BMJ 345: e4757, 2012.

6. Liu F, Yang X, Geng M and Huang M: Targeting ERK, an Achilles' Heel of the MAPK pathway, in cancer therapy. Acta Pharm Sin B 8: 552-562, 2018.

7. Chapman PB, Hauschild A, Robert C, Haanen JB, Ascierto P, Larkin J, Dummer R, Garbe C, Testori A, Maio M, et al: Improved survival with vemurafenib in melanoma with BRAF V600E mutation. N Engl J Med 364: 2507-2516, 2011.

8. Menzies AM, Haydu LE, Visintin L, Carlino MS, Howle JR, Thompson JF, Kefford RF, Scolyer RA and Long GV: Distinguishing clinicopathologic features of patients with V600E and V600K BRAF-mutant metastatic melanoma. Clin Cancer Res 18: 3242-3249, 2012.

9. Sanchez JN, Wang T and Cohen MS: BRAF and MEK Inhibitors: Use and resistance in BRAF-mutated cancers. Drugs 78: 549-566, 2018.

10. Livingstone E, Zimmer L, Piel S and Schadendorf D: PLX4032: Does it keep its promise for metastatic melanoma treatment? Expert Opin Investig Drugs 19: 1439-1449, 2010.

11. Bradish JR, Montironi R, Lopez-Beltran A, Post KM, MacLennan GT and Cheng L: Towards personalized therapy for patients with malignant melanoma: Molecular insights into the biology of BRAF mutations. Future Oncol 9: 245-253, 2013.

12. Hamid O, Cowey CL, Offner M, Faries M and Carvajal RD: Efficacy, Safety, and tolerability of approved combination BRAF and MEK inhibitor regimens for BRAF-mutant melanoma. Cancers (Basel) 11: 1642, 2019

13. Barrueto L, Caminero F, Cash L, Makris C, Lamichhane P and Deshmukh RR: Resistance to checkpoint inhibition in cancer immunotherapy. Transl Oncol 13: 100738, 2020.

14. Flaherty KT, Infante JR, Daud A, Gonzalez R, Kefford RF, Sosman J, Hamid O, Schuchter L, Cebon J, Ibrahim N, et al: Combined BRAF and MEK inhibition in melanoma with BRAF V600 mutations. N Engl J Med 367: 1694-1703, 2012

15. Flaherty KT, Puzanov I, Kim KB, Ribas A, McArthur GA, Sosman JA, O'Dwyer PJ, Lee RJ, Grippo JF, Nolop K and Chapman PB: Inhibition of mutated, activated BRAF in metastatic melanoma. N Engl J Med 363: 809-819, 2010.

16. Chang CY, Park H, Malone DC, Wang CY, Wilson DL, Yeh YM, Van Boemmel-Wegmann S and Lo-Ciganic WH: Immune checkpoint inhibitors and immune-related adverse events in patients with advanced melanoma: A systematic review and network meta-analysis. JAMA Netw Open 3: e201611, 2020.

17. Wolchok JD, Chiarion-Sileni V, Gonzalez R, Rutkowski P, Grob JJ, Cowey CL, Lao CD, Wagstaff J, Schadendorf D, Ferrucci PF, et al: Overall survival with combined nivolumab and ipilimumab in advanced melanoma. N Engl J Med 377: 1345-1356, 2017.

18. Ascierto PA, Del Vecchio M, Robert C, Mackiewicz A, Chiarion-Sileni V, Arance A, Lebbé C, Bastholt L, Hamid O, Rutkowski P, et al: Ipilimumab $10 \mathrm{mg} / \mathrm{kg}$ versus ipilimumab $3 \mathrm{mg} / \mathrm{kg}$ in patients with unresectable or metastatic melanoma: A randomised, double-blind, multicentre, phase 3 trial. Lancet Oncol 18: 611-622, 2017.

19. Hodi FS, Chesney J, Pavlick AC, Robert C, Grossmann KF, McDermott DF, Linette GP, Meyer N, Giguere JK, Agarwala SS, et al: Combined nivolumab and ipilimumab versus ipilimumab alone in patients with advanced melanoma: 2 -year overall survival outcomes in a multicentre, randomised, controlled, phase 2 trial. Lancet Oncol 17: 1558-1568, 2016.

20. Robert C, Schachter J, Long GV, Arance A, Grob JJ, Mortier L, Daud A, Carlino MS, McNeil C, Lotem M, et al: Pembrolizumab versus ipilimumab in advanced melanoma. N Engl J Med 372: $2521-2532,2015$
21. Larkin J, Chiarion-Sileni V, Gonzalez R, Grob JJ, Rutkowski P, Lao CD, Cowey CL, Schadendorf D, Wagstaff J, Dummer R, et al: Five-year survival with combined nivolumab and ipilimumab in advanced melanoma. N Engl J Med 381: 1535-1546, 2019.

22. Dummer R, Ascierto PA, Nathan P, Robert C and Schadendorf D Rationale for immune checkpoint inhibitors plus targeted therapy in metastatic melanoma: A review. JAMA Oncol: Sep 24, 2020 doi: 10.1001/jamaoncol.2020.4401 (Epub ahead of print).

23. Godic A, Poljsak B, Adamic M and Dahmane R: The role of antioxidants in skin cancer prevention and treatment. Oxid Med Cell Longev 2014: 860479, 2014.

24. Ahmad R, Wani A and Ahsan H: Role of antioxidants in pathophysiology. J Med Erudite 2: 9-15, 2013.

25. Bairati I, Meyer F, Gélinas M, Fortin A, Nabid A, Brochet F, Mercier JP, Têtu B, Harel F, Mâsse B, et al: A randomized trial of antioxidant vitamins to prevent second primary cancers in head and neck cancer patients. J Natl Cancer Inst 97: 481-488, 2005.

26. Devasagayam TP, Tilak JC, Boloor KK, Sane KS, Ghaskadbi SS and Lele RD: Free radicals and antioxidants in human health: Current status and future prospects. J Assoc Physicians India 52: 794-804, 2004

27. Ma J, Zhang Q, Chen S, Fang B, Yang Q, Chen C, Miele L, Sarkar FH, Xia J and Wang Z: Mitochondrial dysfunction promotes breast cancer cell migration and invasion through HIF1alpha accumulation via increased production of reactive oxygen species. PLoS One 8: e69485, 2013.

28. Kvam E and Tyrrell RM: The role of melanin in the induction of oxidative DNA base damage by ultraviolet A irradiation of DNA or melanoma cells. J Invest Dermatol 113: 209-213, 1999.

29. Sun L, Guo Y, Zhang Y and Zhuang Y: Antioxidant and Anti-tyrosinase activities of phenolic extracts from rape bee pollen and inhibitory melanogenesis by cAMP/MITF/TYR pathway in B16 mouse melanoma cells. Front Pharmacol 8: 104 2017.

30. Umemura T, Naoi M, Takahashi T, Fukui Y, Yasue T, Ohashi M and Nagatsu T: Cytotoxic effect of 1-methyl-4-phenylpyridinium ion on human melanoma cell lines, HMV-II and SK-MEL-44, is dependent on the melanin contents and caused by inhibition of mitochondrial electron transport. Biochem Med Metab Biol 44 $51-58,1990$.

31. Oliveira S, Coelho P, Prudêncio C, Vieira M, Soares R, Guerreiro SG and Fernandes R: Melanoma and obesity: Should antioxidant vitamins be addressed? Life Sci 165: 83-90, 2016

32. Sarangarajan R, Meera S, Rukkumani R, Sankar P and Anuradha G: Antioxidants: Friend or foe? Asian Pac J Trop Med 10: 1111-1116, 2017.

33. Yang G, Yan Y, Ma Y and Yang Y: Vitamin C at high concentrations induces cytotoxicity in malignant melanoma but promotes tumor growth at low concentrations. Mol Carcinog 56: 1965-1976, 2017.

34. Le Gal K, Ibrahim MX, Wiel C, Sayin VI, Akula MK, Karlsson C, Dalin MG, Akyürek LM, Lindahl P, Nilsson J and Bergo MO: Antioxidants can increase melanoma metastasis in mice. Sci Transl Med 7: 308re308, 2015.

35. Piskounova E, Agathocleous M, Murphy MM, Hu Z, Huddlestun SE, Zhao Z, Leitch AM, Johnson TM, DeBerardinis RJ and Morrison SJ: Oxidative stress inhibits distant metastasis by human melanoma cells. Nature 527: 186-191, 2015.

36. Poljsak B and Milisav I: The role of antioxidants in cancer, friends or foes? Curr Pharm Des 24: 5234-5244, 2018.

37. Yamamoto $\mathrm{Y}$ and Yamashita S: Plasma ratio of ubiquinol and ubiquinone as a marker of oxidative stress. Mol Aspects Med 18 (Suppl): S79-S84, 1997.

38. Saha SP and Whayne TF Jr: Coenzyme Q-10 in human health: Supporting evidence? South Med J 109: 17-21, 2016.

39. Overvad K, Diamant B, Holm L, Holmer G, Mortensen SA and Stender S: Coenzyme Q10 in health and disease. Eur J Clin Nutr 53: 764-770, 1999.

40. Folkers K, Osterborg A, Nylander M, Morita M and Mellstedt H: Activities of vitamin Q10 in animal models and a serious deficiency in patients with cancer. Biochem Biophys Res Commun 234: 296-299, 1997.

41. Folkers K: The potential of coenzyme Q10 (NSC-140865) in cancer treatment. Cancer Chemother Rep 2 4: 19-22, 1974.

42. Rusciani L, Proietti I, Rusciani A, Paradisi A, Sbordoni G, Alfano C, Panunzi S, De Gaetano A and Lippa S: Low plasma coenzyme Q10 levels as an independent prognostic factor for melanoma progression. J Am Acad Dermatol 54: 234-241, 2006. 
43. Jolliet P, Simon N, Barré J, Pons JY, Boukef M, Paniel BJ and Tillement JP: Plasma coenzyme Q10 concentrations in breast cancer: Prognosis and therapeutic consequences. Int J Clin Pharmacol Ther 36: 506-509, 1998.

44. El-Attar E, Kamel A, Karmouty A, Wehida N, Nassra R, El Nemr M and Kandil NS: Assessment of serum CoQ10 levels and other antioxidant markers in breast cancer. Asian Pac J Cancer Prev 21: 465-471, 2020.

45. Lund EL, Quistorff B, Spang-Thomsen M and Kristjansen PE: Effect of radiation therapy on small-cell lung cancer is reduced by ubiquinone intake. Folia Microbiol (Praha) 43: 505-506, 1998.

46. Lockwood K, Moesgaard S and Folkers K: Partial and complete regression of breast cancer in patients in relation to dosage of coenzyme Q10. Biochem Biophys Res Commun 199: 1504-1508, 1994.

47. Roffe L, Schmidt K and Ernst E: Efficacy of coenzyme Q10 for improved tolerability of cancer treatments: A systematic review. J Clin Oncol 22: 4418-4424, 2004.

48. Coenzyme Q10 (PDQ(R)): Health Professional Version. In: PDQ Cancer Information Summaries. Bethesda, MD, 2002.

49. Hong SK, Starenki D, Wu PK and Park JI: Suppression of B-Raf V600E melanoma cell survival by targeting mitochondria using triphenyl-phosphonium-conjugated nitroxide or ubiquinone. Cancer Biol Ther 18: 106-114, 2017.

50. Diplock AT: Safety of antioxidant vitamins and beta-carotene. Am J Clin Nutr 62 (Suppl 6): 1510S-1516S, 1995.

51. Fiedor J and Burda K: Potential role of carotenoids as antioxidants in human health and disease. Nutrients 6: 466-488, 2014.

52. Guruvayoorappan C and Kuttan G: Beta-carotene inhibits tumor-specific angiogenesis by altering the cytokine profile and inhibits the nuclear translocation of transcription factors in B16F-10 melanoma cells. Integr Cancer Ther 6: 258-270, 2007.

53. Pradeep CR and Kuttan G: Effect of beta-carotene on the inhibition of lung metastasis in mice. Phytomedicine 10: 159-164, 2003.

54. IARC Working Group on the Evaluation of Cancer-Preventive Agents: IARC Handbooks of Cancer Prevention. In: Carotenoids. Lyon, 1998

55. Mayne ST, Handelman GJ and Beecher G: Beta-carotene and lung cancer promotion in heavy smokers-a plausible relationship? J Natl Cancer Inst 88: 1513-1515, 1996.

56. Stryker WS, Stampfer MJ, Stein EA, Kaplan L, Louis TA, Sober A and Willett WC: Diet, plasma levels of beta-carotene and alpha-tocopherol, and risk of malignant melanoma. Am J Epidemiol 131: 597-611, 1990.

57. Epstein JH: Effects of beta-carotene on ultraviolet induced cancer formation in the hairless mouse skin. Photochem Photobiol 25: 211-213, 1977.

58. Black HS: Radical interception by carotenoids and effects on UV carcinogenesis. Nutr Cancer 31: 212-217, 1998.

59. Alpha-Tocopherol, Beta Carotene Cancer Prevention Study Group: The effect of vitamin $\mathrm{E}$ and beta carotene on the incidence of lung cancer and other cancers in male smokers. N Engl J Med 330: 1029-1035, 1994.

60. Middha P, Weinstein SJ, Mannisto S, Albanes D and Mondul AM: $\beta$-carotene supplementation and lung cancer incidence in the alpha-tocopherol, beta-carotene cancer prevention study: The role of tar and nicotine. Nicotine Tob Res 21: 1045-1050, 2019.

61. Zhang YP, Chu RX and Liu H: Vitamin A intake and risk of melanoma: A meta-analysis. PLoS One 9: e102527, 2014.

62. Chen HY, Huang SM, Yang CM and Hu ML: Diverse effects of $\beta$-carotene on secretion and expression of VEGF in human hepatocarcinoma and prostate tumor cells. Molecules 17: 3981-3988, 2012.

63. Jang M, Kim SS and Lee J: Cancer cell metabolism: Implications for therapeutic targets. Exp Mol Med 45: e45, 2013.

64. Wang HM, Yang HL, Thiyagarajan V, Huang TH, Huang PJ, Chen SC, Liu JY, Hsu LS, Chang HW and Hseu YC: Coenzyme Q0 enhances ultraviolet b-induced apoptosis in human estrogen receptor-positive breast (MCF-7) cancer cells. Integr Cancer Ther 16: 385-396, 2017.

65. Chen HY, Yang CM, Chen JY, Yueh TC and Hu ML: Multicarotenoids at physiological levels inhibit metastasis in human hepatocarcinoma SK-Hep-1 cells. Nutr Cancer 67: 676-686, 2015

66. McCubrey JA, Steelman LS, Chappell WH, Abrams SL, Wong EW, Chang F, Lehmann B, Terrian DM, Milella M, Tafuri A, et al: Roles of the Raf/MEK/ERK pathway in cell growth, malignant transformation and drug resistance. Biochim Biophys Acta 1773: 1263-1284, 2007.
67. Lobo V, Patil A, Phatak A and Chandra N: Free radicals, antioxidants and functional foods: Impact on human health. Pharmacogn Rev 4: 118-126, 2010.

68. Bowman BA and Russell RM: Present Knowledge in Nutrition. ILSI Press, Washington D.C., 2006.

69. Hajhashemi V, Vaseghi G, Pourfarzam M and Abdollahi A: Are antioxidants helpful for disease prevention? Res Pharm Sci 5: $1-8,2010$.

70. Salganik RI: The benefits and hazards of antioxidants: Controlling apoptosis and other protective mechanisms in cancer patients and the human population. J Am Coll Nutr 20 (Suppl 5): 464S-475S, 2001.

71. Prasad KN, Kumar A, Kochupillai V and Cole WC: High doses of multiple antioxidant vitamins: Essential ingredients in improving the efficacy of standard cancer therapy. J Am Coll Nutr 18: 13-25, 1999.

72. Prasad KN, Cole WC, Kumar B and Prasad KC: Scientific rationale for using high-dose multiple micronutrients as an adjunct to standard and experimental cancer therapies. J Am Coll Nutr 20 (5 Suppl): 450S-463S; discussion 473S-475S, 2001

73. Nechuta S, Lu W, Chen Z, Zheng Y, Gu K, Cai H, Zheng W and Shu XO: Vitamin supplement use during breast cancer treatment and survival: A prospective cohort study. Cancer Epidemiol Biomarkers Prev 20: 262-271, 2011.

74. Lecumberri E, Dupertuis YM, Miralbell R and Pichard C: Green tea polyphenol epigallocatechin-3-gallate (EGCG) as adjuvant in cancer therapy. Clin Nutr 32: 894-903, 2013.

75. Seely D, Wu P, Fritz H, Kennedy DA, Tsui T, Seely AJ and Mills E: Melatonin as adjuvant cancer care with and without chemotherapy: A systematic review and meta-analysis of randomized trials. Integr Cancer Ther 11: 293-303, 2012.

76. Prasad KN and Kumar R: Effect of individual and multiple antioxidant vitamins on growth and morphology of human nontumorigenic and tumorigenic parotid acinar cells in culture. Nutr Cancer 26: 11-19, 1996.

77. Jaber S and Polster BM: Idebenone and neuroprotection: Antioxidant, pro-oxidant, or electron carrier? J Bioenerg Biomembr 47: 111-118, 2015.

78. Picardo M, Grammatico P, Roccella F, Roccella M, Grandinetti M, Del Porto G and Passi S: Imbalance in the antioxidant pool in melanoma cells and normal melanocytes from patients with melanoma. J Invest Dermatol 107: 322-326, 1996.

79. Rusciani L, Proietti I, Paradisi A, Rusciani A, Guerriero G, Mammone A, De Gaetano A and Lippa S: Recombinant interferon alpha-2b and coenzyme Q10 as a postsurgical adjuvant therapy for melanoma: A 3-year trial with recombinant interferon-alpha and 5-year follow-up. Melanoma Res 17: 177-183, 2007.

80. Martucci A, Reurean-Pintilei D and Manole A: Bioavailability and sustained plasma concentrations of CoQ10 in healthy volunteers by a novel oral timed-release preparation. Nutrients 11: 527, 2019.

81. Lee BJ, Tseng YF, Yen CH and Lin PT: Effects of coenzyme Q10 supplementation (300 mg/day) on antioxidation and antiinflammation in coronary artery disease patients during statins therapy: A randomized, placebo-controlled trial. Nutr J 12: 142, 2013.

82. Frontinan-Rubio J, Santiago-Mora RM, Nieva-Velasco CM, Ferrín G, Martínez-González A, Gómez MV, Moreno M, Ariza J, Lozano E, Arjona-Gutiérrez J, et al: Regulation of the oxidative balance with coenzyme Q10 sensitizes human glioblastoma cells to radiation and temozolomide. Radiother Oncol 128: 236-244, 2018.

83. Abdulhasan MK, Li Q, Dai J, Abu-Soud HM, Puscheck EE and Rappolee DA: CoQ10 increases mitochondrial mass and polarization, ATP and Oct4 potency levels, and bovine oocyte MII during IVM while decreasing AMPK activity and oocyte death. J Assist Reprod Genet 34: 1595-1607, 2017.

84. Awa H, Futamura A, Higashiguchi T, Ito A, Mori N, Murai M, Ohara H, Chihara T and Kaneko T: Effects of combined treatment with branched-chain amino acids, citric acid, L-carnitine, coenzyme Q10, zinc, and various vitamins in tumor-bearing mice. Biol Pharm Bull 40: 266-271, 2017.

85. Bahar M, Khaghani S, Pasalar P, Paknejad M, Khorramizadeh MR, Mirmiranpour H and Nejad SG: Exogenous coenzyme Q10 modulates MMP-2 activity in MCF-7 cell line as a breast cancer cellular model. Nutr J 9: 62, 2010.

86. Qi XF, Kim DH, Yoon YS, Kim SK, Cai DQ, Teng YC, Shim KY and Lee KJ: Involvement of oxidative stress in simvastatin-induced apoptosis of murine CT26 colon carcinoma cells. Toxicol Lett 199: 277-287, 2010. 
87. Ashkani-Esfahani S, Bagheri F, Emami Y, Esmaeilzadeh E, Azarpira N, Hassanabadi N, Keshtkar M, Farjam M, Koohi-Hosseinabadi O and Noorafshan A: Protective effects of Co-Enzyme Q10 on thioacetamide-induced acute liver damage and its correlation with behavioral, biochemical, and pathological factors. Iran Red Crescent Med J 18: e29166, 2016.

88. Omenn GS, Goodman GE, Thornquist MD, Balmes J, Cullen MR, Glass A, Keogh JP, Meyskens FL Jr, Valanis B, Williams JH Jr, et al: Risk factors for lung cancer and for intervention effects in CARET, the beta-carotene and retinol efficacy trial. J Natl Cancer Inst 88: 1550-1559, 1996.

89. Druesne-Pecollo N, Latino-Martel P, Norat T, Barrandon E, Bertrais S, Galan P and Hercberg S: Beta-carotene supplementation and cancer risk: A systematic review and metaanalysis of randomized controlled trials. Int J Cancer 127: 172-184, 2010.

90. Sowmya Shree G, Yogendra Prasad K, Arpitha HS, Deepika UR, Nawneet Kumar K, Mondal P and Ganesan P: $\beta$-carotene at physiologically attainable concentration induces apoptosis and down-regulates cell survival and antioxidant markers in human breast cancer (MCF-7) cells. Mol Cell Biochem 436: 1-12, 2017.

91. Shultz TD, Chew BP, Seaman WR and Luedecke LO: Inhibitory effect of conjugated dienoic derivatives of linoleic acid and beta-carotene on the in vitro growth of human cancer cells. Cancer Lett 63: 125-133, 1992.

92. Mebratu Y and Tesfaigzi Y: How ERK1/2 activation controls cell proliferation and cell death: Is subcellular localization the answer? Cell Cycle 8: 1168-1175, 2009.

93. Choi JS, Park SY, Yi EY, Kim YJ and Jeong JW: Coenzyme Q10 decreases basic fibroblast growth factor (bFGF)-induced angiogenesis by blocking ERK activation. Oncol Res 19: 455-461, 2011.

94.Zhao Q, Ma YM, Jing L, Zheng TX, Jiang HF, Li PA and Zhang JZ: Coenzyme Q10 protects astrocytes from ultraviolet B-induced damage through inhibition of ERK 1/2 pathway overexpression. Neurochem Res 44: 1755-1763, 2019.

95. Shin JY, Choi JW, Kim DG, Zhou ZQ, Shin YK, Seo JH, Song HJ, Choi BM, Bae GS and Park SJ: Protective effects of Coenzyme Q10 against acute pancreatitis. Int Immunopharmacol 88: 106900, 2020.
96. Atay C, Kwak T, Lavilla-Alonso S, Donthireddy L, Richards A, Moberg V, Pilon-Thomas S, Schell M, Messina JL, Rebecca VW, et al: BRAF targeting sensitizes resistant melanoma to cytotoxic T cells. Clin Cancer Res 25: 2783-2794, 2019.

97. Pieper N, Zaremba A, Leonardelli S, Harbers FN, Schwamborn M, Lübcke S, Schrörs B, Baingo J, Schramm A, Haferkamp S, et al: Evolution of melanoma cross-resistance to $\mathrm{CD} 8^{+} \mathrm{T}$ cells and MAPK inhibition in the course of BRAFi treatment. Oncoimmunology 7: e1450127, 2018

98. Tan BL, Norhaizan ME, Liew WP and Sulaiman Rahman H: Antioxidant and oxidative stress: A mutual interplay in age-related diseases. Front Pharmacol 9: 1162, 2018.

99. Jhun J, Lee SH, Byun JK, Jeong JH, Kim EK, Lee J, Jung YO, Shin D, Park SH and Cho ML: Coenzyme Q10 suppresses Th17 cells and osteoclast differentiation and ameliorates experimental autoimmune arthritis mice. Immunol Lett 166: 92-102, 2015

100. Pilipow K, Scamardella E, Puccio S, Gautam S, De Paoli F, Mazza EM, De Simone G, Polletti S, Buccilli M, Zanon V, et al: Antioxidant metabolism regulates $\mathrm{CD}^{+} \mathrm{T}$ memory stem cell formation and antitumor immunity. JCI Insight 3: e122299, 2018.

101. Molyneux SL, Young JM, Florkowski CM, Lever M and George PM: Coenzyme Q10: Is there a clinical role and a case for measurement? Clin Biochem Rev 29: 71-82, 2008.

102. Toti E, Chen CO, Palmery M, Villaño Valencia D and Peluso I: Non-provitamin A and provitamin A carotenoids as immunomodulators: Recommended dietary allowance, therapeutic index, or personalized nutrition? Oxid Med Cell Longev 2018: 4637861, 2018

103. Bronte E, Bronte G, Novo G, Rinaldi G, Bronte F, Passiglia F and Russo A: Cardiotoxicity mechanisms of the combination of BRAF-inhibitors and MEK-inhibitors. Pharmacol Ther 192: 65-73, 2018.

This work is licensed under a Creative Commons Attribution-NonCommercial-NoDerivatives 4.0 International (CC BY-NC-ND 4.0) License. 